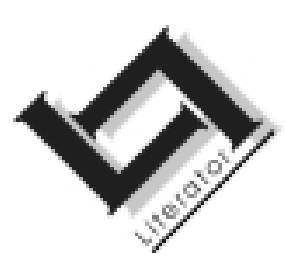

\title{
Taaloordrag in die onderrig van Afrikaans as tweede taal
}

\author{
M. Stander \\ Skool vir Europese Tale \\ Universiteit van die Noorde \\ Qwa-Qwa-kampus \\ PHUTHADITJHABA \\ E-pos: stander@uniqwa.ac.za
}

\begin{abstract}
Language transfer in the teaching of Afrikaans as a second language
\end{abstract}

The biggest problem facing lecturers of Afrikaans as a second language at tertiary institutions is the fact that second-language students are usually taught by non-native speakers at primary and secondary levels. The language form used by these teachers shows clear deviations in comparison to the standardised form. This language form, which can be compared to an interlanguage, has its own distinctive features, and forms the target language of second-language speakers. The short period that second-language speakers are exposed to the standardised form at tertiary level is not enough to improve the situation significantly. The result is that students who qualify themselves as teachers, will transfer the same language form to their pupils at primary and secondary levels. One of the consequences is that this language form develops into a non-standardised form. Examples of deviations from teachers' as well as from students' language forms will be compared to indicate clearly the transfer that takes place.

\section{Inleiding}

Die onderrig van Afrikaans as 'n tweede taal op skool vind heel dikwels plaas deur onderwysers wat self tweedetaalsprekers van Afrikaans is. Die taalvorm wat deur dié onderwysers gebruik word, bevat taalfoute en taalafwykings wat na die taalvorm van hul leerlinge oorgedra word. Hierdie taalvorm het sy eie onderskeidende kenmerke en stem met 'n intertaal ooreen (vgl. Stander, 1998:1). 'n Intertaal word beskryf as 'n taalvorm wat tussen die eerste taal en die tweede of addisionele taal staan (vgl. Ellis, 1985:299) en word deur die tweedetaalspreker geskep 
as ' $n$ strategie ten einde die aanleer van die tweede taal te vergemaklik. 'n Intertaal besit 'n aantal ontwikkelingsvlakke (vgl. Bartning, 1997:15), maar die tyd wat tweedetaalsprekers aan Afrikaans spandeer, is te min om die gaping tussen 'n basiese intertaalvlak en 'n byna-moedertaalvlak van die tweede taal te bereik. Hierdie taalvorm beweeg meer en meer in die rigting van 'n gefossileerde intertaalvorm, in plaas van in die rigting van 'n standaardvorm.

In 'n vorige artikel (vgl. Stander, 2000:63-77) is spesifiek gekonsentreer op die sintaktiese vaardighede van tweedetaalsprekers, en veral onderwysers van Afrikaans. In hierdie artikel handel dit egter oor die oordrag van morfologiese, sintaktiese en leksikaal/semantiese afwykings van onderwysers na dié van hul leerlinge en die ooreenkomste in taalafwykings tussen hierdie twee groepe. Die data word geneem uit voorbeelde van geskrewe werk van studente wat Afrikaans aan die Universiteit in Qwa-Qwa neem. Daar word dus van die veronderstelling uitgegaan dat hierdie studente leerlinge van tweedetaalonderwysers was. Albei artikels is ook gebaseer op 'n Ph.D.-studie, wat die Afrikaans van onderwysers in Qwa-Qwa beskryf (vgl. Stander, 1998). Hierdie artikel fokus veral op die ooreenkomste tussen die taalgebruik van onderwysers en studente en die grammatiese patrone wat daardeur gevestig raak.

Die vorige artikel het verklarings uit Sesotho ingesluit, maar hierdie artikel wil net die ooreenkomste in afwykings tussen die genoemde groepe aantoon om te illustreer dat taaloordrag wel van onderwysers na hul leerlinge plaasvind. Daar sal dus nie na die oorsake vir afwykings uit Sesotho gekyk word of 'n vergelyking tussen Sesotho en Afrikaans getref word nie.

Ter agtergrond tot hierdie artikel, word die onderrigsituasie van Afrikaans as tweede taal op skool in Qwa-Qwa beskryf.

\section{Agtergrond}

Afrikaans in Qwa-Qwa word as 'n keusevak naas Engels op skool aangebied. Nieteenstaande die feit dat Engels as onderrigmedium gebruik word, word Afrikaans as 'n vak gekies. Afrikaans word slegs as 'n geleentheidstaal gebruik en as 'n vak op skool onderrig. Afrikaans as tweede taal kry nie die geleentheid om as 'n natuurlike kommunikasietaal te ontwikkel nie. Die onderwysers en studente wat in hierdie artikel sprake is, het Sesotho as moedertaal en is self tweedetaalsprekers of vreemdetaalsprekers van Afrikaans. Die Afrikaanse taalvorm wat hulle gebruik, is nie die standaardvorm nie en dit is die taalvorm wat aan die leerlinge oorgedra word. Leerlinge word in baie gevalle net aan hierdie 
taalvorm blootgestel en as hulle deur middel van leerboeke kontak met die eerste taal het, kan dit vir hulle as 'n vreemde taal voorkom waarmee hulle geweldige probleme ondervind. Hierdie probleme manifesteer hulleself op tersiêre vlak en dit is dan te laat en selfs onmoontlik om dit te verander (vgl. Stander,1998:1).

Alhoewel die leerlinge met die geskrewe standaardvorm deur middel van handboeke te doen kry, is die rol wat die tweedetaalonderwyser speel baie groot en is daar belangrike feite wat in gedagte gehou moet word. Hierdie feite is onder andere dat handboeke soms heeltemal afwesig is en indien daar wel nog handboeke gebruik word, dit letterkundige werke met 'n poëtiese of idiomatiese inslag is; dat daar nog nie 'n kultuur geskep is om boeke te koop of te lees nie; dat daar nie 'n neiging bestaan om enige literatuur buite die klaskamer te lees nie; en dat letterkundige en ander voorgeskrewe werke deur die onderwyser in die klas voorgelees word, sodat die leerling nooit die geleentheid kry om self te leer lees nie (vgl. Stander, 1998:3). Genoemde feite hou ernstige implikasies vir die bevordering van Afrikaans as 'n tweede taal in hierdie besondere konteks in.

Die ooreenkomste wat in die tweedetaalvorm van Afrikaans van hierdie onderwysers en studente bestaan, dui daarop dat hul taalgebruik geen ontwikkeling of verandering in die rigting van die standaardtaal toon nie (vgl. Stander, 1998:3). Dit beteken dat dieselfde tweedetaalvorm oor en oor gebruik word sonder die moontlikheid van positiewe groei, wat verder impliseer dat hierdie taalvorm gestagneer het (grammatiese patrone is gevestig) en in 'n negatiewe rigting groei.

\section{Taaloordrag as ' $n$ faktor wat tweedetaalgebruik belemmer}

Alhoewel daar ' $n$ aantal faktore is wat tot bogenoemde probleme aanleiding gee, soos onder andere kultuur, situasie, konteks, kommunkasie, persoonlikheid, taalkontak, sosiale afstand, die invloed van die eerste taal, taaloordrag en interferensie (vgl. Stander, 1998:25), word in hierdie artikel spesifiek aan taaloordrag aandag gegee. Daar moet egter eers onderskei word tussen taaloordrag van een taal na 'n ander en taaloordrag van een spreker na 'n ander. Taaloordrag van een taal na 'n ander is slegs by een spreker teenwoordig, waar die spreker taalelemente van een taal na 'n ander oordra. In die taaloordrag van een spreker na 'n ander word die taalvorm van die een spreker na die taalvorm van 'n ander spreker oorgedra (vgl. Stander, 1998:2, 3).

Taaloordrag van een taal na 'n ander word deur Selinker $(1992: 51,101)$ beskryf as die oordrag van eerste- na tweedetaalmateriaal. Volgens 
Odlin (1989:3) is taaloordrag 'n belangrike aspek van niemoedertaalaanleer (vgl. ook Bosch, 1998:175). Littlewood (1984:18), Færch en Kasper (1984:223) en Selinker (1992:172) beskryf taaloordrag as 'n strategie wat deur tweedetaalsprekers gebruik word om hulle met tweedetaalaanleer te help en in so 'n geval vind die taaloordrag van die eerste taal en die tweede taal na die intertaal van die spreker plaas. Die probleem ontstaan egter as die spreker nie 'n geskikte aanleerstrategie in die plek van taaloordrag kan vind nie, 'n faktor wat kommunikasie in die tweede taal kan belemmer. Dit word vererger as daar geen keuse in die eerste taal is nie en die spreker verplig word om 'n element uit die tweede taal te kies. Die tweedetaalspreker se intertaaldata sal aantoon of taalvorme wel oorgedra is of nie.

As taaloordrag egter van een spreker se taalgebruik na 'n volgende spreker se taalgebruik plaasvind, kan dit dan as 'n belemmeringsfaktor in die gebruik van die tweede taal gesien word. Een van die probleme hiermee is dat die tweedetaalkennis van onderwysers nie altyd op die aanvaarbare standaard vir onderrigdoeleindes is nie. Dit skep 'n probleem vir die onderrig van Afrikaans as 'n tweede taal, omdat die tweedetaalonderwysers hul taalgebruik en gebrekkige taalkennis aan die leerlinge oordra (vgl. Stander, 1998:2, 3). Dit is aan laasgenoemde soort taaloordrag wat hierdie artikel aandag wil skenk.

\section{Die ondersoeke}

Ter ondersteuning van hierdie probleem word gebruik gemaak van die data van twee ondersoeke wat gedoen is om die Afrikaanse taalgebruik van studente en onderwysers in Qwa-Qwa te bestudeer. Die eerste ondersoek was vir 'n Ph.D.-studie (Stander, 1998) om vas te stel of die Afrikaans van tweedetaalonderwysers in Qwa-Qwa 'n gefossileerde intertaal is of nie. In hierdie ondersoek is van bandopnames gebruik gemaak. Dit is getranskribeer en die gesproke taal is geanaliseer. In 'n opvolgondersoek gedurende 1999 is die geskrewe werk van studente aan die genoemde universiteit geanaliseer. Die tweede ondersoek is gedoen om vas te stel in hoe 'n mate taaloordrag van onderwysers na leerlinge plaasvind en hoe dit hulle taalgebruik beïnvloed. In die twee ondersoeke het 50 onderwysers in Qwa-Qwa en 75 studente van Afrikaans aan die Qwa-Qwa-kampus deelgeneem. Op grond van hierdie ondersoeke is heelwat ooreenkomste opgemerk wat tot die gevolgtrekking lei dat onderwysers hulle tweedetaalvorme op die taalvorme van hul leerlinge oordra, wat op hul beurt weer in die taalgebruik van studente aan tersiêre inrigtings weerspieël word (vgl. Stander, 1998:3). Vervolgens word 'n vergelyking getref tussen die taalgebruik van die studente en onderwysers. 


\section{5. 'n Vergelyking tussen die taalgebruik van studente en onderwysers}

In hierdie vergelyking is direkte parallelle getrek tussen die afwykings op morfologiese, sintaktiese en leksikaal/semantiese vlak van hierdie twee groepe. Hierdie afwykings word vervolgens een vir een toegelig. Nota: As ' $n$ voorbeeld dié van ' $n$ onderwyser is, word dit met $O$ aangedui en van 'n student, met $\mathrm{S}$.

\subsection{Morfologiese afwykings}

Die morfologiese afwykings van onderwysers vorm vaste patrone wat aan hul leerlinge oorgedra word. Die morfologiese vorme wat bespreek word, is affikse, verkleinwoorde, meervoude en samestellings.

\subsubsection{Affikse}

- Onnodige toevoeging van prefikse, byvoorbeeld 0 : hy het 'n beantwoord gegee; S: hulle verwys dehumaniseer in hulle bekyk. Prefikse word toegevoeg waar slegs stamvorme gebruik moes word. Vergelyk Kotzé (1977:75) en Sema (1987:24).

- Verkeerde suffiks, byvoorbeeld O: uitwerke (uitwerking); $S$ : verwoeste (verwoesting). Die suffiks -ing word met die suffiks -e vervang. Vergelyk Kotzé (1977:75).

- Weglaat van suffiks (attributiewe $e$ ), byvoorbeeld $O$ : ' $n$ vinnig atleet; $S$ : 'n wreed man. Die attributiewe -e word nie tot die adjektief toegevoeg nie. Ponelis (1979:142) stel dit dat daar in sommige gevalle wel vrye sowel as dialektiese wisseling ten opsigte van die -e voorkom. Vergelyk ook Kotzé $(1977: 74,66)$ en De Wet (1996:180).

- Foutiewe invoegsels, byvoorbeeld O: gespraak; S: dronkmisbruik. Die verskillende vorme van dieselfde woord word verwar, byvoorbeeld spreek, gesprek, spraak; dronk, drank, drink. Die verskillende invoegsels wat bestaan, byvoorbeeld ee, e, aa, $0, a$ en $i$ word nie gebruik om die nomina soos byvoorbeeld gesprek en drank te vorm nie (vgl. Combrink, 1989:231).

\subsubsection{Verkleinwoorde}

- Adjektief (verkleining) + verkleiningsuffiks, byvoorbeeld O: klein gebou; S: klein bobbejaan. Die suffiks -tjie word nie saam met 'n adjektief wat verkleining aandui, gebruik nie. In sekere gevalle is dit wel toelaatbaar, vergelyk klein volk. Vergelyk Klopper (1981:275). 
- Verkleiningsuffiks -etjie/-pie, byvoorbeeld O: problemetjie; S: hempetjie. Die verkleiningsuffiks -etjie word in plaas van -pie gebruik. Vergelyk Van Rensburg (1989:459) en Van Wyk (1966:28).

- Verkleiningsuffiks -etjie/ie, byvoorbeeld O: plekketjie; S: hekketjie. Die verkleiningsuffiks -etjie word in plaas van -ie gebruik. Vergelyk Van Rensburg (1989:459) waar tipiese voorbeelde hiervan in Oranjerivier-Afrikaans voorkom, byvoorbeeld hekkietjie, plekkietjie, ensovoorts. Vergelyk ook Mahapa (1997:45) en Nkatini (1978:88).

- Vergroting in plaas van verkleining, byvoorbeeld $O:$ moordstoor in plaas van moordstorie; S: mand in plaas van mandjie). Die ongelede woord word as 'n verkleinwoord aangesien, wat daartoe lei dat 'n vergroting daarvan geskep word. Die tweede lettergreep van die woord lyk baie na 'n verkleiningsuffiks -ie en word daarmee verwar.

\subsubsection{Meervoude}

- Selfstandige naamwoord, enkelvoud + voornaamwoord, meervoud, byvoorbeeld O: die man hulle; S: die kind hulle. Die persoonlike voornaamwoord, derdepersoon, meervoud word saam met 'n selfstandige naamwoord, enkelvoud gebruik, in plaas van 'n selfstandige naamwoord, meervoud. Alhoewel hierdie gevalle meer op sintaktiese afwykings dui, word dit hier as deel van morfologiese afwykings genoem, omdat die afwyking by die meervoudsvorme mans en kinders lê.

- Selfstandige naamwoord, meervoud + voornaamwoord, enkelvoud, byvoorbeeld O: die seuns en vra vir hom; S: die mense hy praat soos die tsotsi. Voornaamwoorde, tweedepersoon, enkelvoud word saam met selfstandige naamwoorde, meervoud in plaas van enkelvoud gebruik

- Lidwoord, onbepaald + selfstandige naamwoord, meervoud, byvoorbeeld O: 'n uie; S: 'n gemeenskaplike kenmerke. Onbepaalde lidwoorde word saam met selfstandige naamwoorde in die meervoudsvorm in plaas van die enkelvoudsvorm gebruik. Ponelis (1979:124) noem voorbeelde waar onbepaalde lidwoorde wel saam met meervoudsvorme gebruik word, byvoorbeeld g'n/geen of niks soos in g'n diere/geen diere/niks diere, maar in die geval van ' $n$ word dit as 'n onbepaalde lidwoord voor enkelvoudige soortnaamwoorde gebruik.

- Meervoud in plaas van enkelvoud, byvoorbeeld O: so hy het nie tyd vir kuiers gehad nie; S: julle moet julle verbeeldings gebruik. 'n Meervoudsvorm word aan 'n nomina toegevoeg waar daar normaalweg nie 'n meervoud moet wees nie. Die woord kuier kan in 'n sekere konteks wel 'n meervoudsvorm neem, byvoorbeeld ons moet twee kuiers 
inwerk met jou volgende besoek, maar gewoonlik word daar gesê: 'n kuier of twee. In die geval van verbeeldings kan dit ook in 'n sekere konteks gebruik word, byvoorbeeld hy is vol verbeeldings (hy is vol fiemies), maar in die bostaande konteks moet die enkelvoud gebruik word. Vergelyk Kotzé (1977:68, 70), Mahapa (1997:44), Wela (1995: 50), Nkatini (1978:88) en De Wet (1996:180).

\subsubsection{Samestellings}

- Omskrywing in plaas van samestelling, byvoorbeeld O: die huis van die planke; S: vorm van 'n taal. In 'n konteks waar daar wel van omskrywings gebruik gemaak kan word, behoort die lidwoord weggelaat te word, byvoorbeeld huis van planke, vorm van taal, ensovoorts. Vergelyk Kotzé (1977:70) en Nkatini (1978:134).

\subsection{Sintaktiese afwykings}

Die sintaktiese afwykings van die onderwysers word as vaste patrone gevestig en aan hul leerlinge oorgedra. Onder die sintaktiese afwykings word die volgende bespreek: voornaamwoorde, voorsetsels, lidwoorde, werkwoorde, adjunkte, ontkenning, woordvolgorde en voegwoorde.

\subsubsection{Voornaamwoorde}

\subsubsection{Persoonlike voornaamwoorde}

- Manlik/vroulik, byvoorbeeld O: die vrou dink terug aan sy ou dae; S: as iemand ' $n$ vrou is, die manier wat hierdie persoon praat met sy man. Die voornaamwoord, derdepersoon, enkelvoud, manlik (sy) word gebruik in plaas van vroulik (haar) as anafoor wat na die antesedent vrou verwys. Die teenoorgestelde kom ook voor waar die voornaamwoord, derdepersoon, enkelvoud, vroulik (haar) gebruik word om na die antesedent man te verwys, byvoorbeeld die man dink aan haar verlede. In die data van die ondersoeke kom laasgenoemde voorbeeld egter nie soveel voor soos die eersgenoemde voorbeeld nie. Vergelyk Mahapa (1997:37), Coetzee en Mahapa (1997:378), Wela (1995:52), Van Wyk (1966:27), Nkatini (1978:94), Van Wyk (1983:165) en De Wet (1996:181).

- Meervoud en enkelvoud, byvoorbeeld O: julle is te haastig om jou papier in te gee; S: ons gebruik my taal sosiaal. Die neiging is om die voornaamwoord (enkelvoud) as anafoor te gebruik wat na die onderwerp (voornaamwoord, meervoud) as antesedent verwys. Die anafoor moet in hierdie geval ook in die meervoudsvorm wees. Dieselfde geld as die antesedent in die enkelvoudsvorm is, byvoor- 
beeld $j y$ is te haastig om jou ... en nie jy is te haastig om julle ... nie. Vergelyk Kotzé (1977:63), Van Wyk (1966:28) en Klopper (1981:280).

- Weglaat van voornaamwoord, byvoorbeeld $\mathrm{O}$ : hy weet dat ( ) hierdie kanse verloor; S: hy weet dat () hierdie taal praat. Die onderwerp, in hierdie geval 'n voornaamwoord, word ná die voegwoord dat weggelaat. Volgens Ponelis (1979:508) volg daar gewoonlik 'n onderwerp na 'n voegwoord by afhanklike volgorde. Vergelyk Kotzé (1977: 46), Wela (1995:32) en Ferreira (1975:55).

\subsubsection{Aanwysende voornaamwoorde}

Hier word veral op die attributiewe gebruik van aanwysende voornaamwoorde gekonsentreer.

- Hierdie in plaas van daardie, byvoorbeeld O: wat is nou hierdie donkie daar?; S: ons bedoel hierdie taal daar. Hierdie in plaas van daardie word saam met die aanwysende woord daar gebruik. In die konteks van hierdie sinne het hierdie en daar dieselfde ruimtelike oriëntering, daarom moet dieselfde vorm van die woord gebruik word, byvoorbeeld hierdie/hier, daardie/daar, ensovoorts. Daar kan as oorbodig beskou word. Vergelyk Wela $(1995: 41,51)$.

- Plasing van daardie een, byvoorbeeld O: dit is 'n bobbejaan daardie een wat dom is; S: dit is die Flaaitaal daardie een wat hulle praat ... Aanwysende woorde word onnodig ingevoeg, soos byvoorbeeld daardie een, om na die onderwerp te verwys. Daardie een kan wel gebruik word, mits die woordvolgorde verander, naamlik daardie dom een is 'n bobbejaan; of daardie een wat dom is, is ' $n$ bobbejaan; of daardie bobbejaan is die een wat dom is. In die geval van die Flaaitaal werk dit nie altyd nie, byvoorbeeld daardie wat hulle praat een, is die Flaaitaal, maar daardie een wat hulle praat, is (die) Flaaitaal; of (daardie) Flaaitaal is die een wat hulle praat.

\subsubsection{Betreklike voornaamwoorde}

- Wat op in plaas van waarop, byvoorbeeld O: die dooie gras wat op hulle nou gaan slaap; S: die voorbeeld wat op dit gebaseer is. Ponelis (1979:465) sê dat wanneer die betreklike voornaamwoord lid is van 'n voorsetselgroep, voorsetselskeiding dikwels intree. Wat op word in plaas van waarop gebruik en voorsetselskeiding word nie toegepas nie, byvoorbeeld die dooie gras wat hulle nou op gaan slaap; die voorbeeld wat dit op gebaseer is. (Laasgenoemde sin kan ook anders geïnterpreteer word: die voorbeeld wat daarop gebaseer is). Vergelyk Mahapa (1997:40), Coetzee en Mahapa (1997:380), Wela (1995:41) en De Wet (1996:181). 


\subsubsection{Besitlike voornaamwoorde}

- Besitlike voornaamwoord in plaas van se, byvoorbeeld O: die kat haar lêplek; S: die spreker sy taal. Besitlike voornaamwoorde word in die plek van se gebruik. Alhoewel die besitlike voornaamwoord en die se-konstruksie albei besitting aandui, kan die een nie summier in die plek van die ander gebruik word nie. Vergelyk Mahapa (1997:39), Coetzee en Mahapa (1997:379) en Wela (1995:51).

- Se in plaas van besitlike voornaamwoord, byvoorbeeld O: hoekom het Ciske se moeder vermoor?; S: hy sê ook dat () belangrik is ook se opmerking dat ... Die se-konstruksie word in die plek van die besitlike voornaamwoord gebruik. Ook hier kan die se-konstruksie en die besitlike voornaamwoord nie summier plekke ruil nie. Vergelyk Kotzé $(1977: 64,65)$.

- Weglating, byvoorbeeld O: hoekom het (hy ) () pa se plek net so gelos? S: as hy () sintuie gebruik ...

\subsubsection{Wederkerende voornaamwoorde}

- Weglating, byvoorbeeld O: dan herinner hy () aan sy pa ...; S: die situasie waarin hy () in 'n gegewe oomblik bevind ... Die wederkerende voornaamwoord word weggelaat. Vergelyk Mahapa (1997: 40) en Coetzee en Mahapa (1997:380).

\subsubsection{Vraende voornaamwoorde en vraagwoorde}

- Vraende voornaamwoord/vraagwoord aan die einde, byvoorbeeld O: hy het dit nou gemaak van wat?; S: hy het gesê wat/waar ...? Die vraende voornaamwoord wat of die vraagwoord waar word telkens aan die einde van die sin gebruik, in plaas daarvan om die vraagwoord aan die begin van die sin te gebruik, byvoorbeeld: Waarvan het hy dit gemaak? / Wat het hy gesê? ensovoorts. In sommige kontekste is dit wel toelaatbaar (vgl. Ponelis 1979:381) veral as daar klem op wát gelê word, byvoorbeeld: Hy het dit gemaak van wát? / Hy het gesê wát? Vergelyk Nkatini (1978:102).

- Die gebruik van waarmee i.p.v. wat/waarvan, byvoorbeeld O: waarmee was hy nou besig om te doen?; S: en waarmee praat hulle nou? Waarmee word in die plek van 'n vraende voornaamwoord soos wat of waarvan gebruik, byvoorbeeld: Wat was hy besig om te doen? / Waarvan/wat praat hulle nou? 


\subsubsection{Voorsetsels}

Heelwat afwykings en ooreenkomste ten opsigte van die gebruik van voorsetsels is by albei groepe opgemerk. Hier sal egter net 'n paar voorbeelde ter illustrasie gegee word:

- Weglating, byvoorbeeld O: hoe kan jy nou () jou ou dae nou dink?; S: hulle verwys () iets as homogeen. Die voorsetsel word weggelaat. Daar is talle voorbeelde in die data waar nie net sekere voorsetsels nie, maar enige voorsetsel weggelaat kan word. Vergelyk Kotzé (1977:49), Wela (1995:30) en De Wet (1996:181).

- Toevoegings, byvoorbeeld O: daar sien ons met die woord; S: in die gebruikers van Afrikaans (se) verskeidenheid is duidelik ... Voorsetsels word ingevoeg waar dit onnodig is. Vergelyk Kotzé (1977:54), Wela (1995:34) en De Wet (1996:181).

- Verkeerde voorsetsel, byvoorbeeld O: die huis met die planke (van planke); S: al die mense op die land (in die land). Die verkeerde voorsetsel word gebruik. Vergelyk Kotzé (1977:35), Wela (1995:29), Van Wyk (1966:28), Meiring (1991:44) en Nkatini (1978:147).

\subsubsection{Lidwoorde}

Heelwat afwykings ten opsigte van die gebruik van lidwoorde deur albei groepe is opgemerk. Enkele ooreenkomste wat aangetref is, is die volgende:

- Die in plaas van 'n, byvoorbeeld O: hulle noem dit die sinkplaat; S: Chomsky was ook die strukturalis ... Die bepaalde lidwoord die word saam met nie-spesifieke konsepte (nomina) gebruik in plaas van die onbepaalde lidwoord ' $n$.

- ' $\boldsymbol{n}$ in plaas van die, byvoorbeeld O: hy is 'n skrywer van die gedig; S: hy is 'n eerstepersoonverteller ... Die onbepaalde lidwoord ' $n$ word saam met spesifieke konsepte gebruik in plaas van die bepaalde lidwoord die. In hierdie konteks word daar na 'n spesifieke persoon verwys. Vergelyk Nkatini (1978:137).

- Weglaat van lidwoorde, byvoorbeeld O: na ( ) baie lang tyd; S: ... wat deur ( ) groep mense en bepaalde geografiese gebied ... Die onbepaalde lidwoord ' $n$ word uit die sin weggelaat in gevalle waar dit nie weggelaat kan word nie. Vergelyk Kotzé (1977:45), Wela (1995: 31) en Nkatini (1978:139).

- Toevoeg van lidwoorde, byvoorbeeld O: 'n voorbeelde; S: 'n verbeeldings. Die onbepaalde lidwoord ' $n$ word tot die sin toegevoeg. Die onbepaalde lidwoord ' $n$ word saam met die meervoudsvorm van 
die nomina gebruik. Vergelyk Kotzé (1977:53), Mahapa (1997:37), Nkatini (1978:139) en De Wet (1996:181).

- Lidwoord + eienaam, byvoorbeeld O: die Ciske; S: die Chomsky/De Saussure. Die bepaalde lidwoord die word saam met 'n eienaam gebruik, wat normaalweg nie só gebruik word nie. In 'n konteks waar daar spesifiek na 'n sekere persoon verwys word, is dit wel toelaatbaar, byvoorbeeld dié Chomsky/De Saussure/Ciske.

- Onbepaalde lidwoord + massanaamwoord, byvoorbeeld O: 'n seep, 'n water; S: William Labov gee 'n goeie inligting om hoe taal (te) gebruik ... Die onbepaalde lidwoord ' $n$ word saam met massanaamwoorde gebruik wat normaalweg nie so gebruik word nie.

\subsubsection{Werkwoorde}

Die ooreenkomste wat by werkwoorde aangetref is, is die volgende:

- Hoofwerkwoorde: weglating, byvoorbeeld $\mathrm{O}$ : in die bedrywende vorm ( ) die onderwerp voor die ... (kom); S: hulle het (die) teenoorgestel(de) van (as) die strukturalisme (gedoen). Die hoofwerkwoord word uit die sin weggelaat. Vergelyk Wela (1995:32) en De Wet (1996:181).

- Koppelwerkwoorde: weglating, byvoorbeeld O: dit wat in sy pa se geboutjie ( ) onthou; S: maar hulle ( ) (ge)intereseer(d) in die taalvermoë van die spreker. Die koppelwerkwoord is word uit die sin weggelaat. Vergelyk Kotzé (1977:47), Wela (1995:32), Nkatini (1978: 144) en De Wet (1996:181).

- Deeltjiewerkwoorde: uiteenplasing, byvoorbeeld O: ... dat ek toe sal stem om (met) Ciske te praat; $\mathrm{S}$ : ... dat hulle aan sal beveel om die taal ... Die deeltjiewerkwoord word uiteengeplaas in plaas daarvan om dit as 'n eenheid te gebruik, byvoorbeeld: ... dat ek sal toestem/ ... dat hulle sal aanbeveel.

- Deeltjiewerkwoorde as eenheid, byvoorbeeld O: toe aansteek hy die vuur by die donkie; S: hy sê sosiolinguistiek insluit taal en mense. Die deeltjiewerkwoord word as 'n eenheid gebruik in plaas daarvan om dit uiteen te plaas, byvoorbeeld: Toe steek hy die vuur aan / Hy sê sosiolinguistiek sluit taal en mense in. In hierdie geval moet die werkwoord eers gebruik word en daarna die deeltjie, steek + aan, sluit + in. Die deeltjie word dikwels met voorsetsels verwar. Vergelyk Kotzé (1977:76) en Nkatini (1978:142).

- Hulpwerkwoorde van modaliteit, byvoorbeeld O: hy't nie daarvan gehou dat Wim vir Sid in die rede wil val nie; S: ... dat hy die volgende gevolgtrekking kan gemaak het. Die verkeerde temporele 
waarde word aan die hulpwerkwoord van modaliteit toegevoeg. Omdat dit hier om die verlede tyd gaan, moet wil met wou vervang word en kan met kon. Volgens Ponelis (1979:246) het wou en kon temporele (verledetydsverwysende) waarde. Vergelyk Kotzé (1977: 80) en De Wet (1996:181).

- Hulpwerkwoord van tyd: weglating, byvoorbeeld $O$ : ... wat die diere op die grond gewys () dat dit gaan reën; S: ... dat een persoon ('n) taalvorm gepraat ( ). Die hulpwerkwoord van tyd (het) word verkeerdelik weggelaat.

\subsubsection{Adjunkte}

- Herhaling van adjunkte, byvoorbeeld O: die belangrikste hier wat ek hier wil kom bespreek; S: die tsotsitaal daar is 'n Flaaitaal daar. Die bywoordelike bepaling van plek word onnodig ingevoeg of herhaal, byvoorbeeld die belangrikste wat ek hier (wil) kom bespreek ... / die tsotsitaal (daar) is Flaaitaal. Vergelyk Klopper (1981:252).

- Omruiling van adjunkte, byvoorbeeld O: daai klok waaroor hulle hier praat ... hy sê daar was ...; S: dis nou die taal van hier wat hulle praat daar ... Die bywoordelike bepaling van plek daar word by die tweede adjunk in plaas van hier gebruik, terwyl die eerste verwysing na plek hier is.

- Onnodige toevoeging en herhaling van adjunkte, byvoorbeeld $\mathrm{O}$ : elke keer as hierdie atleet dan hardloop, dan het hy ook die hardlopery baie geniet; S: hulle terme wat die onderwysers dan gebruik soos voorbereidings, hulle gebruik dan soos afkortings. Die adjunk dan word onnodig in die sin gebruik of herhaal, ongeag of dit tyd of voorwaarde aandui. Vergelyk Kotzé (1977:57).

- Skakeladjunkte, byvoorbeeld O: het jou pa ook nie 'n werkplek nie?; $\mathrm{S}$ : is die taal ook nie 'n standaardtaal nie? Die skakeladjunk ook word in die verkeerde posisie in die sin geplaas. As ook voor die ontkenning nie geplaas word, is die bedoeling dat die pa eintlik niks het nie (of soos baie ander mense) of dat die taal nie 'n standaardtaal of enige ander soort taal is nie (of soos baie ander tale). As ook ná die ontkenning geplaas word, byvoorbeeld Het jou pa nie ook 'n werkplek nie?/ is die taal nie ook 'n standaardtaal nie?, kan die bedoeling wees dat die pa mos wel nog 'n werkplek ook het of dat die taal, behalwe 'n standaardtaal, nog iets anders ook is. In hierdie geval kan dit ook as 'n stelling gesien word. Die interpretasie van hierdie voorbeeld lê in sy semantiese aard.

- Kwalifiseerders: herhaling, byvoorbeeld O: maar ons kan eintlik, ons kan sê ... hy was eintlik krom ... dat die man eintlik oud was; S: 
dit eintlik staan vir "more pa"... eintlik. Die kwalifiseerder eintlik word onnodig herhaal, moontlik ter wille van beklemtoning.

\subsubsection{Ontkenning}

- Verkeerde plasing in sin, byvoorbeeld O: ... nie aan sy ou dae nie soos julle; S: ... nie vir Afrikaans nie soos Engels ... Die tweede ontkenningsvorm nie word voor die vergelykingsvorm soos in plaas van daarna gebruik, byvoorbeeld ... nie aan sy ou dae soos julle nie; nie vir Afrikaans soos Engels nie.

- Weglaat van tweede nie, byvoorbeeld $O$ : hy praat nie met daardie persoon ( ); S: ... en dit is nie belangrik ( ). In hierdie geval word die tweede nie weggelaat. Vergelyk Kotzé (1977:48), Wela (1995:31) en Nkatini (1978:150).

- Invoeging van 'n derde nie, byvoorbeeld $O$ : ... wat nie heilig is nie vir jou nie; S: ... volgens die ondersoek nie Flaaitaal nie huistaal is nie. 'n Derde nie word onnodig ingevoeg. Dit versteur ook die woordvolgorde van die sin. Vergelyk Kotzé (1977:59) en De Wet (1996: 181).

\subsubsection{Woordvolgorde}

- Woordvolgorde in die hoofsin, byvoorbeeld O: Ciske ook het by Bruis se huis gegaan; S: Brand ook sê dat 'n persoon wat Flaaitaal kan praat ... Die SVO-woordvolgorde word nie gevolg nie. Dit is verkeerd as gevolg van die plasing van die skakeladjunk ook. Dit moet ná die werkwoord in die sin staan, byvoorbeeld Ciske het ook ... / Brand sê ook ... Vergelyk Mahapa (1997:32), Wela (1995:28), Nkatini (1978:90), Meiring (1991:44) en De Wet (1996:181).

- Woordvolgorde in die bysin, byvoorbeeld 0 : dat die gedig is in hoofletters geskryf; S: Claassen noem dat die ondersoek toon ook aan dat Flaaitaal ... Die woordvolgorde in die bysin is dieselfde as dié van die hoofsin ná die voegwoord dat, naamlik SVO(X): (die gedig) + (is geskryf) + (in hoofletters) en (die ondersoek) + (toon ... aan) + (ook ...) in plaas van die $\mathrm{SO}(\mathrm{X}) \mathrm{V}$-volgorde: voegwoord (dat) + (die gedig) + (in hoofletters $)+($ is geskryf) en voegwoord (dat) + (die ondersoek $)+$ (ook) + (aantoon). Vergelyk Mahapa (1997:33), Van Wyk (1983:165) en De Wet (1996:181).

\subsubsection{Voegwoorde}

Behalwe die woordvolgorde wat nie ná die voegwoord verander nie, is daar ook afwykings by voegwoorde self aangetref: 
- Weglaat van voegwoord, byvoorbeeld O: dus het ek gesê () hierdie pa 'n ambagsman was ... (dat); S: variëteit(e) sluit hiervolgens eenhede groter as dialekte ( ) eenhede kleiner as dialekte in ... (en). Voegwoorde word weggelaat. Vergelyk Kotzé (1977:49), Mahapa (1997:35) en Coetzee en Mahapa (1997:377).

- Verkeerde voegwoord, byvoorbeeld O: sy moeder wou nie as Ciske by die ... (dat); S: die terme langue en competence beteken as dieselfde ... (dat). As word in plaas van dat gebruik. Vergelyk Kotzé (1977:38), Mahapa (1997:35) en Wela (1995:30).

\subsection{Leksikaal/semantiese afwykings}

Die volgende leksikaal/semantiese afwykings en ooreenkomste van die onderwysers en studente se taalgebruik het in die data voorgekom:

- Verkeerde vertaling, byvoorbeeld O: polieskantore in plaas van polisiekantore (police); S: patiensie in plaas van geduld (patience). Daar word verkeerd uit Engels vertaal, byvoorbeeld polisiekantore na polieskantore na aanleiding van die Engelse police en geduld na patiensie uit die Engelse patience. Vergelyk Kotzé (1977:88, 91), Meiring (1991:44) en Wela (1995:39).

- Engelse woorde, byvoorbeeld O: Or vir of ; S: prisoner vir prisonier; pauses vir pouses. In hierdie geval word die Engelse woord direk, sonder vertaling, in 'n sin gebruik. Vergelyk Kotzé (1977:85), Mahapa (1997:61), Van Wyk (1983) en De Wet (1996:181).

- Verkeerde woordkeuse, byvoorbeeld O: hy ken waar Ciske is (weet); $\mathrm{S}$ : wat bedoel hierdie strukturalisme (beteken). Verkeerde woordkeuse word gemaak as gevolg van Engelse invloed: ken en weet kan albei met know vertaal word; bedoel en beteken kan albei met mean vertaal word. Vergelyk Kotzé (1977:84, 86), Mahapa (1997:57), Nkatini (1978:112) en De Wet (1996:181).

\section{Gevolgtrekking}

Die bostaande vergelyking van afwykings tussen die taalgebruik van die onderwysers en die studente toon genoeg ooreenkomste om te bewys dat die niestandaardtaalvorme van die onderwysers na die taalvorme van hul leerlinge oorgedra word. Die gevolg is dat hierdie taalvorme nie in die rigting van die standaardvorm groei nie, maar in 'n teenoorgestelde, negatiewe rigting. Afwykende grammatiese patrone word sodoende gevestig. 
Dit hou ernstige gevolge vir die onderrig van Afrikaans as 'n tweede taal in, wat beslis reggestel moet word om die proses in 'n teenoorgestelde, positiewe rigting te laat beweeg.

\section{Bibliografie}

Bartning, I. 1997. Portrait of the so-called 'advanced' learner and variety, especially in French L2. EUROSLA '7 Proceedings, p. 15-25. Barcelona : Universitat Pompeu Fabra.

Bosch, B. 1998. Die akademiese Afrikaans van Engelssprekende universiteitstudente. Tydskrif vir Taalonderrig, 32(3):173-190.

Coetzee, A.E. \& Mahapa, M. 1997. Noord-Sotho Afrikaans-onderwysstudente se intertaal - 'n gevallestudie. Tydskrif vir Taalonderrig, 31(4):370-384.

Combrink, J.G.H. 1989. Afrikaanse morfologie: 'n oorsig. In: Botha, T.J.R. Inleiding tot die Afrikaanse taalkunde. Pretoria : Academica. p. 220-254.

De Wet, A.S. 1996. Swartafrikaans as 'n aanleerdersvariëteit in die Vrystaat: 'n studie aan die hand van intertaalteorie. Bloemfontein : UVS. (Ph.D.-proefskrif.)

Ellis, R. 1985. Understanding second language acquisition. Oxford : University Press.

Færch, C. \& Kasper, G. 1984. Strategies in interlanguage communication. London \& New York : Longman.

Ferreira, J.A. 1975. 'n Leerboek vir Suid-Sotho. Pretoria : Van Schaik.

Klopper, A.H. 1981. Die stand van Afrikaans onder die Suid-Sotho in die R.S.A.: 'n sosiolinguistiese ondersoek. Bloemfontein : UVS. (Ph.D.-proefskrif.)

Kotzé, E.F. 1977. 'n Sosiolinguistiese ondersoek na sintaktiese, morfologiese en leksikale afwykings in die Afrikaans van Xhosas. Johannesburg : Universiteit van die Witwatersrand. (M.A.-verhandeling.)

Littlewood, W. 1984. Foreign and second language learning: Language acquisition research and its applications for the classroom. Cambridge : University Press.

Mahapa, M.J. 1997. Taalprobleme van Noord-Sothosprekende onderwysstudente wat Afrikaans gaan onderrig. Johannesburg : RAU. (M.A.-verhandeling.)

Meiring, B. 1991. T2-Afrikaans as universiteitskursus. Tydskrif vir Taalonderrig, 25(2): 31-62.

Nkatini, N.L. 1978. Die Afrikaansvaardigheid van 'n proefgroep Tsongas - 'n sosiolinguistiese studie. Pietersburg : Universiteit van die Noorde. (M.A.-verhandeling.)

Odlin, T. 1989. Language transfer: cross-linguistic influence in language learning. Cambridge : Cambridge University Press.

Ponelis, F.A. 1979. Afrikaanse sintaksis. Pretoria : Van Schaik.

Selinker, L. 1992. Rediscovering interlanguage. London \& New York : Longman.

Sema, E.M. 1987. Die bepaling van die kommunikatiewe behoeftes in Afrikaans vir swart sekondêre skole met die oog op die opstel van 'n sillabus. Johannesburg : RAU. (M.A.-verhandeling.)

Stander, M. 1998. Die Afrikaans van T2-onderwysers in Qwa-Qwa: 'n gefossileerde intertaal? Sebokeng : Vista. (Ph.D.-proefskrif.)

Stander, M. 2000. Sintaktiese vaardighede van tweedetaalsprekers van Afrikaans. Tydskrif vir Taalonderrig, 34(1):63-77, Maart.

Van Rensburg, M.C.J. 1989. Soorte Afrikaans. In: Botha, T.J.R. Inleiding tot die Afrikaanse taalkunde. Pretoria : Academica. p. 436-467.

Van Wyk, E.B. 1966. Woordversteurings in die Afrikaans van Bantoes. Taalfasette, 2:27-48. 
Van Wyk, E.B. 1983. Gepidginiseerde Afrikaans. In: Claassen, G.N. \& Van Rensburg, M.C.J. (reds.) Taalverskeidenheid: 'n Blik op die spektrum van taalvariasie in Afrikaans. Pretoria : Academica. p. 162-170.

Wela, V.P. 1995. Die rol van moedertaalversteuring in die Afrikaans van Zoeloesprekende leerlinge. Zoeloeland: Universiteit van Zoeloeland. (M.A.-verhandeling.)

\section{Kernbegrippe:}

afwykings van Standaardafrikaans taaloordrag van onderwysers na leerlinge tweedetaalonderrig van Afrikaans tweedetaalverwerwing van Afrikaans

\section{Key concepts:}

deviations from Standard Afrikaans language transfer from teachers to pupils second-language acquisition of Afrikaans second-language teaching of Afrikaans 